\title{
The Development of a TRIC Agent (Chlamydia trachomatis) and its Associated Polysaccharide in Suspended Cell Cultures
}

\author{
By A. J. GARRETT* AND MARGARET J. HARRISON† \\ The Lister Institute of Preventive Medicine, \\ Chelsea Bridge Road, London SWI W $8 \mathrm{RH}$
}

(Received 20 March 1973)

\begin{abstract}
SUMMAR Y
The growth of large quantities of a TRIC agent and the concomitant production of polysaccharide were studied in BHK2I and L cell cultures in suspension. The maximum concentrations of elementary bodies and polysaccharide/culture were attained at about the same time $(60 \mathrm{~h})$ after infection in both cell systems. The yield of elementary bodies from a $\mathrm{I} 1$ culture was equivalent to the maximum obtained from a total area of $8000 \mathrm{~cm}^{2}$ of BHK2I monolayers. Polysaccharide found in the medium was probably derived from disrupted inclusion bodies. It is postulated that synthesis of the polysaccharide is directed by the TRIC agent but controlled by the host cell.
\end{abstract}

\section{INTRODUCTION}

Chlamydiae are obligate intracellular micro-organisms that fall into two main groups, A and B (Gordon \& Quan, I965). Members of group A are sensitive to the sulphonamides and develop within well-defined cytoplasmic inclusions that fill with a glucose polymer as infective particles form, whereas group B chlamydiae are sulphonamide-resistant and are characterized by diffuse inclusions which contain no glucose polymer.

The chlamydiae can be propagated in the yolk sac of embryonated eggs and many strains have been adapted to grow in cell culture monolayers. However, chemical and biochemical investigations have been hindered by difficulties in growing and purifying large quantities of the micro-organisms. Higashi, Tamura \& Iwanaga (1962) and Tamura \& Higashi (I963) overcame many of these problems by growing a chlamydia group B strain in cell cultures in suspension. The present paper describes the development of trachoma/inclusion conjunctivitis (TRIC) agent (a group A chlamydia) and the concomitant production of polysaccharide in I to 21 volumes of suspension cultures of baby hamster kidney (BHK2I) and L cells.

\section{METHODS}

Cell cultures. Monolayers of BHK2I cells (Stoker \& Macpherson, I964) and BHK2I cells adapted to grow in suspension (Capstick, 1963) were grown and maintained as described by Blyth, Taverne \& Garrett (197I). L cells (Earle, I943) adapted to grow in suspension were kindly supplied by Professor G. P. Manire, University of North Carolina, Chapel Hill, U.S.A. They were grown in Earle's lactalbumin hydrolysate (Gibco MII) containing $0.1 \% \mathrm{NaHCO}_{3}, 0 . \mathrm{I} \%$ yeastolate (Difco), $0.35 \%$ glucose, I0 \% (v/v) calf serum (Flow Laboratories Ltd), and streptomycin sulphate $(100 \mu \mathrm{g} / \mathrm{ml})$. Maintenance medium was

\footnotetext{
* Present address: National Institute for Biological Standards and Control, Holly Hill, Hampstead $\mathrm{NW}_{3}$ 6RB.

$\dagger$ Present address: Institut für Biochemie II, 69 Heidelberg, Akademiestrasse 5, Germany.
} 
growth medium without serum and also contained neomycin sulphate $(25 \mathrm{u} . / \mathrm{ml})$. One to two 1 cultures in suspension were stirred magnetically in 41 screw-capped bottles or $60 \mathrm{ml}$ volumes were shaken in $250 \mathrm{ml}$ conical flasks on an L.H.E. Mk V orbital shaker (L.H. Engineering Co. Ltd, Stoke Poges, Buckinghamshire). Growing cells were diluted with fresh medium to a concentration of about $5 \times 10^{5}$ cells $/ \mathrm{ml}$ every 2 or 3 days.

TRIC agent. The fast-killing variant (Taverne, Blyth \& Reeve, 1964) of strain TRIC/2/ GB/MRC-4/ON (Jones, I 96I) was used. Stocks of TRIC agent were partially purified from infected yolk sac material and stored and assayed as described by Taverne \& Blyth (I97I).

Preparation of TRIC agent inoculum for suspended cells. The concentration of yolk-sac contaminants in partially purified agent was reduced further by one passage through BHK2I monolayer cells: BHK2I monolayers were grown for 3 days in $250 \mathrm{ml}$ polystyrene tissue culture flasks (Falcon Plastics Cat. no. 3024), and were infected by centrifuging on to the cells an average of two infective particles/cell (Blyth et al. 197I). The monolayer cell surface area was approximately $80 \mathrm{~cm}^{2}$. The cells were removed in growth medium 40 to $48 \mathrm{~h}$ later by gently rolling glass beads over the monolayer. The cells were disrupted ultrasonically at 0 to $4{ }^{\circ} \mathrm{C}$ in a Soniprobe tank type $113 / 2 \mathrm{~A}$ (Dawe Instruments Ltd) so that the inclusions were completely disintegrated. The infectivity of such preparations decreased rapidly on storage even at $-70^{\circ} \mathrm{C}$, so they were used immediately after preparation, to infect cells in suspension. One bottle of infected cells usually yielded $4 \times 10^{9}$ to $\mathrm{I} \times 10^{10}$ inclusion-forming units (i.f.u.), when titrated in BHK2I monolayers by the method of Taverne \& Blyth (197I).

Infection of cells in suspension. L and BHK2I cells were treated identically. They were collected by centrifuging at $600 \mathrm{~g}$ for Io min and resuspended in maintenance medium to a concentration of $\mathrm{I} \times 10^{7}$ cells $/ \mathrm{ml}$. The concentrated cells ( 150 to $200 \mathrm{ml}$ ), in a cottonplugged $250 \mathrm{ml}$ bottle, were stirred at about Ioo rev./min at $36^{\circ} \mathrm{C}$ with an estimated Io to 40 infective TRIC particles/cell. At a multiplicity of infection of less than Io, fewer cells were infected; if the multiplicity of infection was 100 or more, many cells were killed. The $\mathrm{pH}$ of the suspension was maintained at $7 \cdot 2$ to $7 \cdot 6$ by adding $2 \mathrm{M}$-tris (tris hydroxy methyl amino methane) when required. The infected cells were stirred for $\mathrm{I} \cdot 5$ to $2 \mathrm{~h}$ and then poured into I to 21 of fresh maintenance medium in a 41 screw-capped bottle to give a final concentration of $\mathrm{I} \times 10^{6} \mathrm{cells} / \mathrm{ml}$. They were stirred at $100 \mathrm{rev} . / \mathrm{min}$ at $36{ }^{\circ} \mathrm{C}$ for the duration of the experiment.

Measurement of infectivity. Samples (Io $\mathrm{ml}$ ) of infected suspension cultures were taken at intervals throughout the incubation and centrifuged at $600 \mathrm{~g}$ for $\mathrm{I} 0 \mathrm{~min}$. The supernatant fluids were retained for measurement of extracellular infectivity. The cells were resuspended in $2 \mathrm{ml}$ growth medium and disrupted ultrasonically. The infectivity of this homogenate and of the supernatant fluid was measured in BHK2I monolayers by the method of Taverne \& Blyth (I97I) and expressed as i.f.u./ml of suspension culture.

Total elementary bodies. These were measured by dark-field microscopy (Reeve \& Taverne, 1962).

Iodine staining of cells in suspension. Samples of infected cells were diluted with an equal vol. of Lugol's iodine. Inclusions appeared as well-defined light brown vacuoles containing particles in vigorous motion.

Measurement of polysaccharide in suspension cultures. Samples $(20 \mathrm{ml})$ of the cultures were centrifuged at $600 \mathrm{~g}$ for Io min. The cells were resuspended in I ml water and disrupted ultrasonically. Trichloroacetic acid (TCA) was added to a final concentration of $5 \%(\mathrm{w} / \mathrm{v})$. The suspensions were kept at $0^{\circ} \mathrm{C}$ throughout these treatments and the TCA soluble fractions were analysed immediately or stored at $-20^{\circ} \mathrm{C}$. Preliminary experiments 
showed that TCA extracted all the polysaccharide from infected BHK2I cells and that it precipitated material that would otherwise have interfered with the anthrone-carbohydrate reaction. Polysaccharide in the extracts was measured by the anthrone method of Mokrasch ( I954) after free glucose had been destroyed by boiling in $5 \mathrm{~N}-\mathrm{KOH}$ (van der Vies, I954). The medium, collected after removal of the cells, was also treated with TCA at a final concentration of $5 \%(\mathrm{w} / \mathrm{v})$ and centrifuged at $600 \mathrm{~g}$ for ro min. The supernatant fluid was dialysed against at least three changes of distilled water (I00 times the vol. in the dialysis bag), adjusted to $\mathrm{pH} 8$ with $\mathrm{NaOH}$ and then concentrated on a rotary evaporator to onetenth of its original volume. Polysaccharide was assayed as described above. Glucose standards were used and polysaccharide was expressed as glucose equivalents. Samples of suspension taken at the same time as those for polysaccharide analysis were stained with iodine and the concentration of inclusions was determined.

Enzymatic assay of polysaccharide glucose. Polysaccharide was degraded with amyloglucosidase (Sigma London Chemical Co. Ltd) and the glucose released was then measured by the glucose oxidase method (Johnson \& Fusaro, I966). The glucose oxidase mixture (Glucostat Regular, Worthington Biochemical Corp.) was reconstituted in $0.5 \mathrm{M}$-tris buffer (Dahlqvist, 1964) to inhibit the activity of carbohydrase contaminants in the mixture.

\section{RESULTS}

\section{Yield of TRIC elementary bodies}

Fig. I summarizes the results of three experiments in which BHK2 $\mathrm{r}$ cells in suspension were infected with TRIC agent. In one experiment most of the cells were badly damaged $50 \mathrm{~h}$ after infection and representative samples of the culture could not be taken after $46 \mathrm{~h}$. Cells containing inclusions seemed to be more susceptible to mechanical damage, and variation in stirring speed of the magnet may have caused disintegration of the cells. In other experiments more than $70 \%$ of the original cells were undamaged after $48 \mathrm{~h}$ as judged by permeability to eosin; 20 to $30 \%$ remained undamaged after $65 \mathrm{~h}$ and $\mathrm{I}$ to $8 \%$ after 5 days. Maximum yields of elementary bodies (about $10^{9} / \mathrm{ml}$ of culture) were obtained 50 to $70 \mathrm{~h}$ after infection when $95 \%$ of the TRIC agent was still associated with host cells. The ratio of total to infective particles was approx. one throughout the incubations.

Similar results were obtained with infected L cells in suspension (Fig. I). The yield of cell-associated infective agent (about $10^{9}$ i.f.u./ml of culture) was maximal 45 to $60 \mathrm{~h}$ after infection. The cell concentration decreased during the course of the experiment, and taking into account the $\mathrm{L}$ cell concentrations at particular times, the yield of infective TRIC particles/cell increased from I.6 at 24 h to $200,470,680,960$ and 1400 at $30,36,42,48$ and $72 \mathrm{~h}$ respectively.

\section{Yield of polysaccharide}

Polysaccharide in BHK2I cells was first detected by the anthrone-sulphuric acid test $24 \mathrm{~h}$ after infection. Infectivity and the amount of polysaccharide/culture reached their maximum values at about the same times (Fig. I, 2). Inclusions in BHK2I cells first reacted with iodine about $24 \mathrm{~h}$ after infection; thereafter they stained progressively more deeply and increased in size until by $48 \mathrm{~h}$ they occupied most of the cytoplasm. Those few cells that remained whole 5 days after infection were distorted by enormous inclusions. Inclusions in L cells often stained poorly with iodine and were then recognizable only by their characteristic shape and the elementary bodies they contained. Glucose released by amyloglucosidase accounted for 90 to $94 \%$ of the polysaccharide isolated from infected BHK2I cells. 


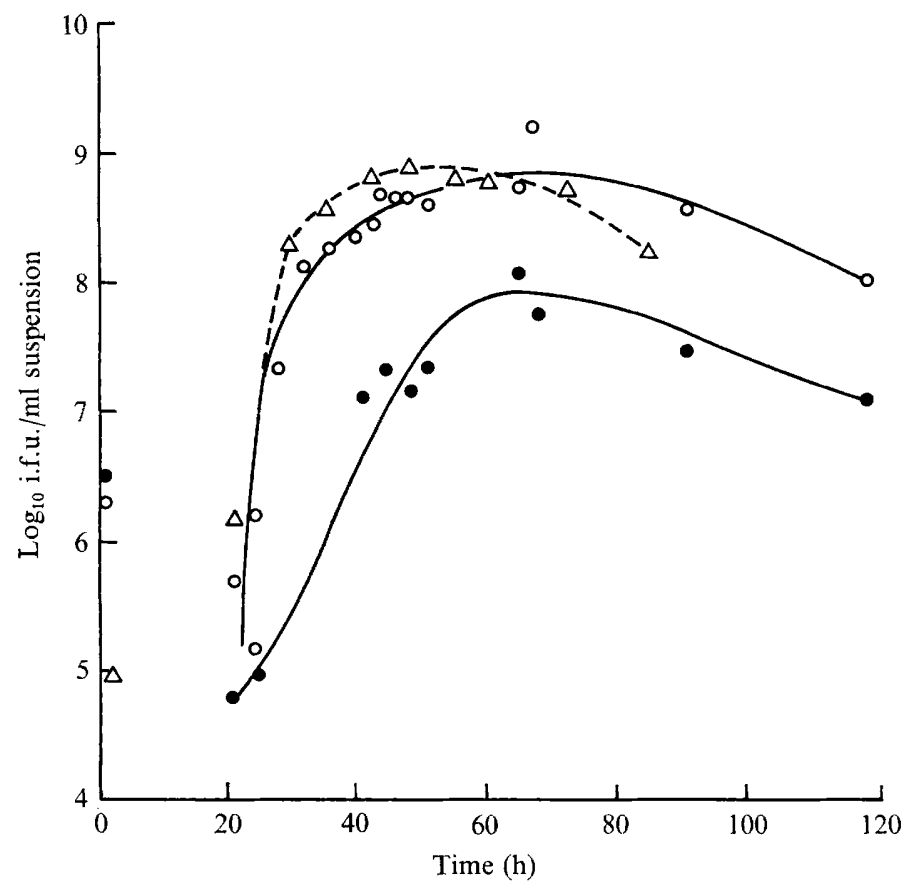

Fig. I. The yield of infective TRIC agent from suspended cells. Results for BHK2I cells are from three experiments and show agent associated with cells $(-\mathrm{O}-)$ and released into medium $(-\longrightarrow)$; the results for $\mathrm{L}$ cells $\left(---\Delta_{---}\right)$are for cell associated agent only.

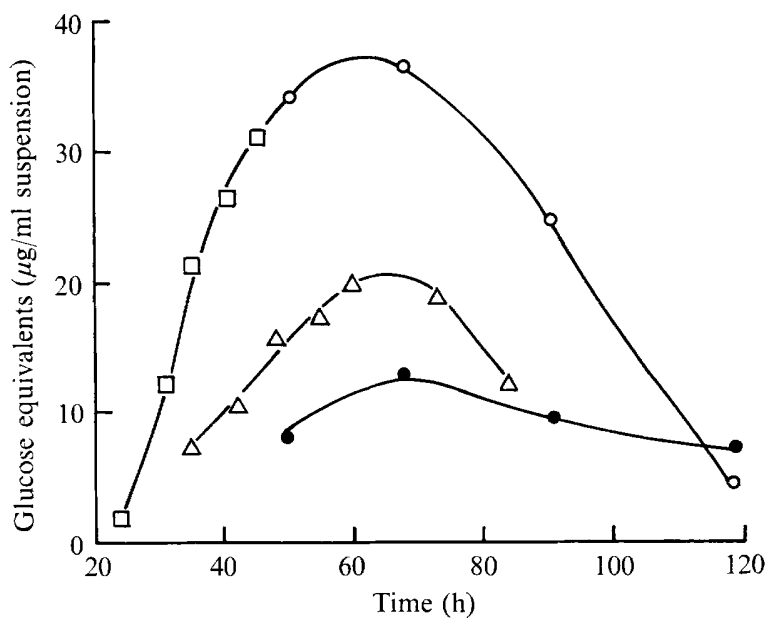

Fig. 2. Polysaccharide in TRIC-infected suspended cell cultures. Cells and medium were separated by centrifugation at $600 \mathrm{~g}$ for Io min. Polysaccharide in TCA extracts was measured by the anthrone method and expressed as glucose equivalents. $\square, O$, BHK2I cells (two separate experiments); $\triangle$, L cells; $\bullet$, BHK2I cell medium. 


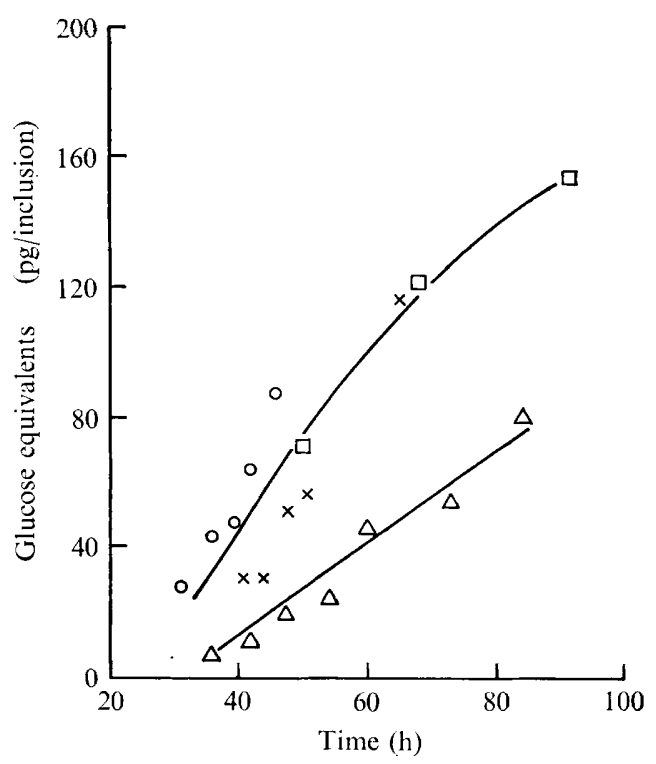

Fig. 3. Polysaccharide in TRIC-infected suspended cells. The results are expressed as glucose equivalents/inclusion. $O, \square, \times$, BHK2I cells; $\triangle, L$ cells.

Approximately $20 \%$ of the total polysaccharide found in the BHK2I cultures at $48 \mathrm{~h}$ was free in the medium; this proportion increased, probably as a result of cell disruption, as incubation continued. As expected from microscopy of iodine-stained cells, the amount of polysaccharide/inclusion increased throughout the whole incubation period (Fig. 3). Polysaccharide in homogenates of infected cells was rapidly degraded unless enzymatic activity was inhibited, and the decrease in total polysaccharide content of the culture was probably due to amylolytic activity within damaged cells or in the medium.

The polysaccharide content of infected $L$ cells was less than that of infected BHK2I cells in the experiments depicted in Fig. 3. This was not invariably so; yields of polysaccharide varied from batch to batch but the reason for this is unknown. When a single batch of infected L cells was used, increasing the glucose concentration of the maintenance medium to twice or three times the normal $(0.35 \%)$ did not significantly alter the amount of polysaccharide produced.

\section{DISCUSSION}

The methods described for the production of large quantities of TRIC agent could provide sufficient starting material for detailed analyses of the infective elementary bodies and the more actively metabolic forms of TRIC agent, the reticulate bodies. The multiplicity of infection (Io to 40) was chosen to give the highest number of infected cells and the greatest yield of elementary bodies per culture; under these conditions, the yield (about $10^{12}$ i.f.u.) from I 1 of culture containing $10^{9}$ infected BHK2 I or L cells was equivalent to the maximum that would be obtained from a total surface area of $8000 \mathrm{~cm}^{2}$ of BHK2I monolayer cells (i.e. the yield from one hundred $250 \mathrm{ml}$ Falcon Plastics flasks). The yield and ratio of infective to total elementary bodies were similar to those from infected monolayer cells (Evans, 1972). Provided that most of the infected cells remained whole the yield of elementary bodies/ $\mathrm{ml}$ of culture was greatest about $60 \mathrm{~h}$ after infection. 
The exact composition and structure of the polysaccharide in the inclusions of group A chlamydiae are unknown. On the basis of its reaction with iodine and its digestion by salivary amylase (Rice, 1936) the polysaccharide has been referred to as glycogen. Our results support this conclusion. However, although glucose was the only sugar found by chromatography of acid hydrolysates of polysaccharide extracted from BHK2 I cells (A. J. Garrett, to be published), an assay using amyloglucosidase and glucose oxidase indicated that either 5 to $10 \%$ of the polysaccharide was not glucose or it was not glucose bound as in glycogen.

The site and mode of synthesis of this polymer have not been clearly demonstrated. When several batches of suspended cells were examined $48 \mathrm{~h}$ after infection with TRIC agent, there was no correlation between the yields of polysaccharide and the number of infective organisms that each cell in a batch had received, or between the yields of polysaccharide and infective elementary bodies/inclusion remaining at any one time. It might be concluded, therefore, that the host cell, not the micro-organism, synthesized the polysaccharide. However, recent evidence from Jenkin \& Fan (I97I) and A. Evans (personal communication) suggests that the micro-organism itself produces an enzyme (or enzymes) that directs polysaccharide synthesis in TRIC-infected cells. Jenkin \& Fan (I97I) demonstrated that homogenates of TRIC-infected HeLa cells incorporated $\left[{ }^{14} \mathrm{C}\right]$ glucose from ADP- $\left[{ }^{14} \mathrm{C}\right]$ glucose into a product that co-precipitated with shellfish glycogen. ADP-glucose was used preferentially by the infected cells and UDP-glucose by normal HeLa cells. These results imply the presence of an enzyme coded for by the micro-organism but it was not possible to determine whether micro-organism or host synthesized the enzyme. Evans measured the amount of polysaccharide produced $48 \mathrm{~h}$ after infection of BHK2I cells with TRIC agent. She showed that polysaccharide production was inhibited in the presence of chloramphenicol which was added within $24 \mathrm{~h}$ of infecting the cells, at a concentration that inhibits bacterial but not mammalian protein synthesis. This suggests that the micro-organism synthesizes the enzyme system responsible for polysaccharide formation.

When these results are considered together, we may postulate that although the polysaccharide produced by TRIC-infected cells is synthesized by enzymes from the microorganism, the host cell controls the amount of polymer formed.

As in TRIC infections of monolayer cultures (Reeve \& Taverne, 1967; Evans, 1972), polysaccharide production in suspended cells accompanied the development of elementary bodies. Although the maximum polysaccharide concentration/culture was reached 50 to $60 \mathrm{~h}$ after infection of suspended cells, the average polysaccharide content of inclusions continued to increase for at least $30 \mathrm{~h}$ after this (Fig. 3). This apparent anomaly resulted from disruption of some inclusions and the subsequent enzymatic degradation of polysaccharide during the incubation. Reeve \& Taverne (1967) and Evans (1972) showed that the average polysaccharide content of inclusions in BHK2I monolayer cells decreased rapidly after attaining its maximum $48 \mathrm{~h}$ after infection; the decrease was attributed to leakage from the cells and not to their rupture. In suspended cells the amount of polysaccharide released from disrupted inclusions could account for that found in the medium. Inclusions in undamaged suspended cells increased in size, polysaccharide content and intensity of staining with iodine for at least $90 \mathrm{~h}$, so if leakage of polysaccharide occurred it was more than compensated for by synthesis within the inclusion. Polysaccharide in TRIC-infected suspended cells may well be retained more efficiently than that in monolayer cultures; BHK2I cells spread on glass are permeable to eosin, whereas cells grown in the same way and removed from the glass support with EDTA and trypsin are impermeable to the dye (A. Evans, personal communication). 
We are grateful to Miss L. Hughes and Miss N. Yianni for excellent technical assistance, and to Professor L. H. Collier, Dr J. Taverne and Dr W. A. Blyth for helpful criticism. We thank the Wellcome Trust for the award of a research fellowship to M.J.H.

\section{REFERENCES}

Blyth, W. A., TAyerne, J. \& GarretT, A. J. (I971). Trachoma inclusions separated from cells. In Trachoma and Related Disorders Caused by Chlamydial Agents. Proceedings of a Symposium held in Boston, Massachusetts, pp. 79-87. Edited by R. L. Nichols. Amsterdam: Excerpta Medica.

CAPSTICK, P. B. (I963). Growth of baby hamster kidney cells in suspension. Proceedings of the Royal Society of Medicine 56, 1062-1064.

DAHLQVist, A. (I964). Method for assay of intestinal disaccharidases. Analytical Biochemistry 7, I8-25.

EARLE, W. R. (1943). Production of malignancy in vitro. IV. The mouse fibroblast cultures and changes seen in the living cell. Journal of the National Cancer Institute 4, I65-21 2.

Evans, A. (1972). The development of TRIC organisms in cell cultures during multiple infection. Journal of Hygiene 70, 39-48.

GoRDON, F. B. \& QUAN, A. L. (1965). Occurrence of glycogen in inclusions of the psittacosis-lymphogranuloma venereum-trachoma agents. Journal of Infectious Diseases II5, 186-196.

Higashi, N., Tamura, A. \& Iwanaga, M. (I962). Developmental cycle and reproductive mechanism of the meningopneumonitis virus in strain L cells. Annals of the New York Academy of Sciences 98, I00-12I.

JENKIN, H. M. \& FAN, V. S. C. (197I). Contrast of glycogenesis of Chlamydia trachomatis and Chlamydia psittaci strains in HeLa cells. In Trachoma and Related Disorders Caused by Chlamydial Agents. Proceedings of a Symposium held in Boston, Massachusetts, pp. 52-59. Edited by R. L. Nichols. Amsterdam: Excerpta Medica.

Johnson, J. A. \& FusAro, R. M. (I966). The quantitative enzymic determination of animal liver glycogen. Analytical Biochemistry 15, I40-149.

JoNes, B. R. (I96I). TRIC virus infections in London. Transactions of the Ophthalmological Society of the United Kingdom 8I, 367-378.

MoKRASCH, L. C. (1954). Analysis of hexose phosphates and sugar mixtures with the anthrone reagent. Journal of Biological Chemistry 208, 55-59.

ReEve, P. \& TAVERNE, J. (1962). A simple method for total particle counts of trachoma and inclusion blennorrhoea viruses. Nature, London 195, 923-924.

ReEVE, P. \& TAVERNE, J. (1967). Strain differences in the behaviour of TRIC agents in cell cultures. American Journal of Ophthalmology 63, II67-1173.

Rice, C. E. (1936). The carbohydrate matrix of the epithelial-cell inclusion in trachoma. American Journal of Ophthalmology I9, I-8.

StOKeR, M. \& MACPHERSON, I. (1964). Syrian hamster fibroblast cell line BHK2I and its derivatives. Nature, London 203, I355-I357.

Tamura, A. \& Higashi, N. (1963). Purification and chemical composition of meningopneumonitis virus. Virology 20, 596-604.

TAVerne, J., Blyth, W. A. \& ReEVE, P. (I964). Toxicity of the agents of trachoma and inclusion conjunctivitis. Journal of General Microbiology 37, 27I-275.

TAVERNE, J. \& BLYTH, W. A. (I97I). Interactions between trachoma organisms and macrophages. In Trachoma and related disorders caused by chlamydial agents. Proceedings of a Symposium held in Boston, Massachussets, pp. 88-I07. Edited by R. L. Nichols. Amsterdam: Excerpta Medica.

VAN DER VIES, J. (I954). Two methods for the determination of glycogen in liver. Biochemical Journal 57, 410$4 \mathrm{I} 6$. 